\title{
Revisão bibliográfica: Avaliação da incidência de refluxo vesico-ureteral e seus impactos para rins transplantados.
}

\section{Renan José Rigonato*, Marcelo Lopes de Lima, Marilda Mazzali, Graziele Ambrosio}

\section{Resumo}

O impacto da presença de transplante vesico-ureteral sobre a função do rim transplantado é bastante incerto. O intuito deste trabalho é realizar uma ampla busca na literatura disponível e compilar estudos que tragam dados acerca do tema, afim de determinar se a presença de refluxo pode trazer impactos negativos para o enxerto renal.

\section{Palavras-chave:}

Refluxo vesico-ureteral, transplante, rim.

\section{Introdução}

As complicações urológicas são relativamente infrequentes no transplante renal. Neste âmbito pode-se destacar o refluxo vesico-ureteral (RVU), caracterizado pelo fluxo anormal de urina, que ocorre no sentido da bexiga para o ureter ou pelve renal.

A real prevalência de refluxo vesico-ureteral é incerta, com estudos chegando a valores bastante distintos, de 1 a $86 \% .{ }^{1}$

Está documentado na literatura que o refluxo parece estar relacionado ao aumento de infecções do trato urinário e que pode estar associado a maior deterioração da função do enxerto renal a longo prazo. Porém não há um consenso quanto o real impacto do RVU sobre tais aspectos. ${ }^{1,3}$

A avaliação dessa complicação é feita através da uretrocistografia miccional, a qual não é realizada de forma rotineira no pós-operatório do paciente submetido ao transplante renal, pois está documentado na literatura que a sua realização implica em um maior índice de infecções do trato urinário, podendo ocasionar prejuízo para o paciente. ${ }^{2}$

\section{Resultados e Discussão}

Pesquisou-se nas bases de dados "PUBMED", "GOOGLE SCHOLAR", "MEDLINE", "LILACS" E "COCHRANE LIBRARY os termos Kidney transplant and vesicoureteral reflux"; "Reflux in Kidney transplant"; "Complications in kindney transplant".

Obteve-se um total de 76 artigos, que foram selecionados conforme a figura 1.

A busca resultou em um total de 1.341 pacientes que foram submetidos a transplante renal e posteriormente avaliados com uretrocistografia miccional.

Tal como o levantamento prévio da literatura, os artigos selecionados evidenciaram uma prevalência bastante variável de RVU, com média ponderada de $19,7 \%$, variando de $10,5 \%$ a $78,1 \%$

Pode-se notar que aspectos relacionados ao doador e receptor não possuem efeito sobre a incidência de refluxo vesico-ureteral, tal como idade média do receptor e tipo de doador- vivo ou cadavérico.

Também se percebeu que a técnica de reimplante ureteral não apresentou impacto estatístico sobre a ocorrência de RVU.

Todos os estudos trouxeram tentaram demonstrar o questionamento inicial sobre a possível correlação entre RVU e alteração da sobrevida do enxerto renal. $O$ estudo de INOUE et ${ }^{3}$ al foi o único a conseguir correlacionar alteração da função renal nas primeiras 24 horas com a presença de refluxo, porem o mesmo não constatou tal alteração a longo prazo. Todos os outros artigos analisados evidenciaram não haver correlação entre ambos os fatores.

Acerca da presença de RVU e de infecção urinaria todos os artigos foram unanimes em demonstrar que não há associação entre os fatores.

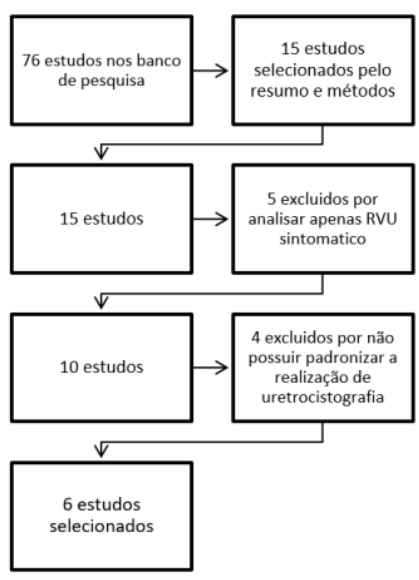

Figura 1. Fluxograma do processo de inclusão dos estudos na revisão.

\section{Conclusões}

O refluxo vesico-ureteral é de fato uma complicação urológica comum no enxerto renal, ainda que possua prevalência bastante variável. A sua presença não possui impacto negativo na função do enxerto renal e nem está associado a maior incidência de infecções urinarias.

Referências bibliográficas:

1Engelstein D, Dorfman B, Yussim A, Shmueli D, Bar Nathan N, Shaharabani E, Shapira Z. A Critical Appraisal of Vesiculoureteral Reflux in Long-Term Renal Transplantation Recipients: Prospective Study. Transplantation Proceedings. 1997;29:136-137

2Lee S, Moon HH, Kim T-S, Roh Y, Song S, Shin M, et al. Presence of vesicoureteral reflux in the graft kidney does not adversely affect longterm graft outcome in kidney transplant recipients. Transplant Proc 2013;45:2984-7.

Inoue T., Satoh S, Saito M. Correlations between pretransplant dialysis duration, bladder capacity, andprevalence bladder capacity vesicoureteral reflux to the graft. Transplantation. $22011 ; 92 \quad$ (3):311315 